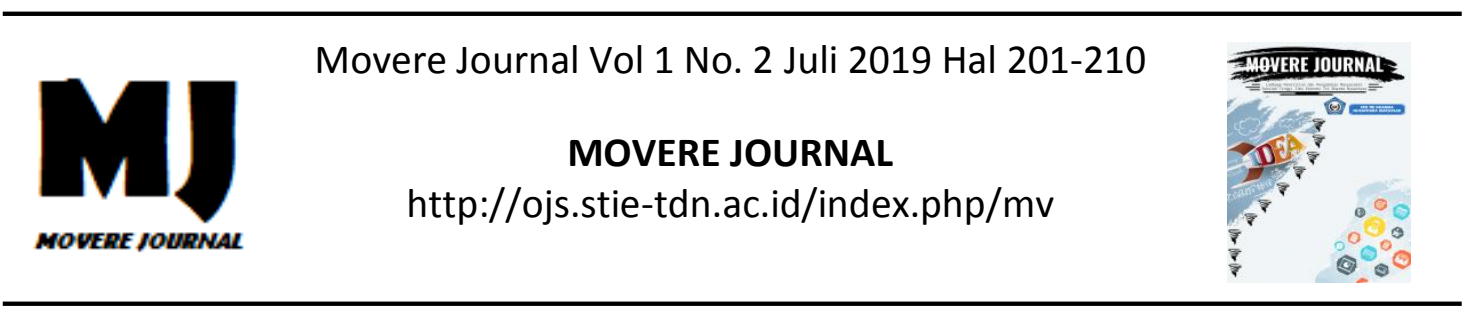

\title{
PENGARUH KEPUASAN KERJA TERHADAP KINERJA KARYAWAN PADA PDAM TIRTA JENEBERANG KABUPATEN GOWA
}

\author{
Desy Purnamasari ${ }^{1)}$ Muhammad Ilham Alimuddin ${ }^{2)}$ \\ STIE Tri Dharma Nusantara
}

\begin{abstract}
Abstrak : Tujuan penelitian ini adalah untuk mengetahui pengaruh kepuasan kerja terhadap kinerja karyawan pada PDAM Tirta Jeneberang Kabupaten Gowa. Jenis data yang digunakan adalah data kualitatif dan kuantitatif, sumber data yang digunakan adalah data primer dan sekunder. Populasi dan sampel penelitian sebanyak 42 orang karyawan. Metode penelitian yang digunakan adalah analisis deskriptif dan statistik. Berdasarkan hasil penelitian dan pembahasan sebelumnya, maka diperoleh nilai regresi yakni $\mathrm{Y}=10,4+0,78 \mathrm{x}$ korelasi sebesar 0,49 koefisien determinasi sebesar 0,2401 dan melalui perhitungan uji t-hitung dilihat bahwa t hitung lebih besar dari t tabel yakni 3,55>1,684. Maka benar kepuasan kerja berpengaruh positif terhadap kinerja karyawan pada PDAM Tirta Jeneberang Kabupaten Gowa, dengan demikian hipotesis dalam penelitian ini diterima.
\end{abstract}

Keyword : Kepuasan kerja, kinerja karyawan

\section{PENDAHULUAN}

Suatu perusahaan akan meningkat kinerjanya bila adanya kerjasama dan hubungan yang baik antara pimpinan dan karyawannya. Karena dengan meningkatkan kinerja karyawan otomatis akan meningkatkan kinerja perusahaan. Karyawanpun sebaiknya diperlakukan seperti partner usaha dan bukan sebagai buruh semata. Untuk mencapai tujuan tersebut, maka perusahaan harus dapat mencetak dan merealisasikan sumber daya manusia yang handal, karena peranan sumber daya manusia sangat penting dan menjadi kunci keberhasilan suatu perusahaan. Untuk itu perusahaan harus memperhatikan pemeliharaan hubungan yang terjadi secara terus menerus antara karyawan dan atasan perusahaan. Kepuasan kerja adalah perasaan dan penilaian seseorang atas pekerjaannya, khususnya mengenai kondisi kerjanya dalam hubungannya dengan apakah pekerjaannya mampu memenuhi harapan, kebutuhan dan keinginannya. Kepuasan kerja yang tinggi akan mempengaruhi kondisi kerja kearah yang lebih positif dan dinamis sehingga dapat memberikan keuntungan yang nyata.

Kepuasan kerja bagi seorang karyawan merupakan faktor yang amat penting karena kepuasan yang diperolehnya akan turut menentukan sikap positif terhadap pekerjaan. Perasaan puas dalam bekerja dapat menimbulkan dampak positif terhadap perilaku, seperti misalnya tingkat kedisiplinan semangat kerja yang cenderung meningkat. Kepuasan kerja juga berhubungan dengan outcomes seperti kinerja,sehingga apabila kepuasan semakin tinggi maka akan menimbulkan semangat dalam bekerja. Dengan demikian seorang akan lebih mudah mencapai tingginya kinerja.

Dalam suatu kelompok atau organisasi terdiri atas individu- 
individu, dan setiap individu sering mengalami situasi dan penerimaan atau presepsi yang berbeda di dalam memandang sesuatu. Jika diantara mereka ada yang tidak puas, ini menunjukkan ada perasaannya yang terganggu atau penerimaan atas presepsi yang tidak terpenuhi dan akan memberikan dampak bagi perusahaan itu sendiri.

Suatu perusahaan harus mengoptimalkan kinerja para karyawannya untuk mencapai tujuan dan memenuhi kebutuhan perusahaan. Kinerja karyawan adalah perilaku atau tindakan relevan dengan tujuan organisasi. Pada umumnya karyawan akan berkomitmen dan puas dengan pekerjaanya jika mereka puas dengan kondisi pekerjaan itu sendiri.

Karyawan dengan komitmen organisasi yang tinggi lebih berorientasi terhadap kerja daripada karyawan lainnya. Mereka mendapatkan kepuasan lebih dari pekerjaan dan melihat pekerjaan mereka sebagai pemenuhan pribadi mereka.

PDAM atau Perusahaan Daerah Air Minum merupakan salah satu unit usaha milik daerah dan mempunyai tugas melaksanakan, mengelola prasarana dan sarana penyediaan air bersih bagi masyarakat umum dengan tujuan memberikan pelayanan air secara adil dan terus menerus PDAM terdapat disetiap provinsi, kabupaten, dan kota madya diseluruh Indonesia. PDAM merupakan perusahaan daerah sebagai sarana penyedia air bersih yang diawasi dan dimonitor oleh aparat-aparat eksekutif maupun legislatif daerah dan difungsikan untuk kepentingan umum demi tercapainya keadilan sosial bagi seluruh rakyat Indonesia sehingga masyarakat dapat merasakan pemerataan infrastruktur dari pemerintah setempat. Adapun maksud dan tujuan dari penelitian ini adalah untuk mengertahui pengaruh kepuasan terhadap kinerja karyawan pada PDAM Tirta Jeneberang Kab.Gowa.

\section{TELAAH LITERATUR DAN PENGEMBANGAN HIPOTESIS}

\section{Manajemen Sumber Daya Manusia}

Manajemen sumber daya manusia (MSDM) merupakan bidang strategis dari organisasi. Manajemen sumber daya manusia harus di pandang sebagai perluasan dari pandangan tradisional untuk mengelola orang secara efektif dan untuk itu membutuhkan pengetahuan tentang perilaku manusia dan kemampuan mengelolanya. Semua potensi SDM tersebut berpengaruh terhadap upaya organisasi dalam mencapai tujuan.

Menurut Simamora dalam Edy (2009:5) "Manajemen sumber daya manusia adalah pendayagunaan, pengembangan, penilaian, pemberian balas jasa, dan pengelolaan individu anggota organisasi atau kelompok pekerja".

Menurut Schuler, et al dalam Edy (2009:6) : "Manajemen sumber daya manusia adalah pengakuan tentang pentingnya tenaga kerja organisasi sebagai sumber daya manusia yang sangat penting dalam memberi kontribusi bagi tujuan-tujuan organisasi, dan menggunakan beberapa fungsi dan kegiatan untuk memastikan bahwa SDM tersebut di gunakan secara efektif dan adil bagi kepentingan individu, organisasi, dan masyarakat".

Menurut Dessler dalam Edy (2009:5) :

Manajemen sumber daya manusia adalah dapat di definisikan sebagai suatu kebijakan dan praktik yang 
dibutuhkan seseorang yang menjalankan aspek "orang" atau sumber daya manusia dari posisi seorang manajemen, meliputi, perekrutan, penyaringan.

\section{Kepuasan Kerja}

Menurut Wexley dan Yukl dalam Wilson (2012:327) "kepuasan kerja generelisasi sikap-sikap terhadap pekerjaannya. Bermacam-macam sikap seseorang terhadap pekerjaannya mencerminkan pengalaman yang menyenangkan dan tidak menyenangkan dalam pekerjaannya serta harapan-harapannya terhadap pengalaman masa depan”.

Menurut Handoko dalam Edy (2009:75) "kepuasan kerja adalah keadaan emosional yang menyenangkan atau tidak menyenangkan bagi para karyawan memandang pekerjaan mereka". Kepuasan kerja mencerminkan perasaan seseorang terhadap pekerjaannya. Ini tampak dalam sikap positif karyawan terhadap karyawan dan segala sesuatu yang di hadapi di lingkungan kerjanya.

Kepuasan kerja didefinisikan sebagai suatu sikap umum seseorang terhadap pekerjaannya. Definisi ini mengandung pengertian yang luas. Dengan kata lain kepuasan kerja merupakan penjumlahan yang rumit dari sejumlah unsur pekerjaan yang terbedakan dan terpisahkan satu sama lain (discrete job elements). As'ad dalam Edy (2009:75) Mengemukakan bahwa penelitian dibidang kepuasan kerja, terdapat tiga macam arah, yaitu:

1. Usaha untuk menemukan faktorfaktor yang menjadi sumber kepuasan kerja serta kondisi-kondisi yang mempengaruhinya dengan mengetahui hal tersebut dapat menciptakan kondisi-kondisi tertentu agar karyawan bisa lebih bergairah dan merasa bahagia dalam bekerja

2. Usaha untuk melihat bagaimana dampak dari kepuasan kerja terhadap sikap dan tingkah laku karyawan.

3. Dalam rangka usaha mendapatkan rumusan yang lebih tepat dan bersifat komprehensif mengenai kepuasan kerja.

Berdasarkan pendapat di atas maka disimpulkan bahwa kepuasan kerja karyawan merupakan masalah penting yang diperhatikan dalam hubungannya dengan produktivitas kerja karyawan dan ketidakpuasan sering dikaitkan dengan tingkat tuntutan dan keluhan pekerjaan yang tinggi.

\section{Teori Kepuasan Kerja}

A.A Anwar (2016:120) mengemukakan bahwa teori-teori kepuasan kerja yaitu:

\section{Teori keseimbangan (Equity theory)}

Adapun komponen dari teori ini adalah input yaitu semua nilai yang diterima pegawai yang dapat menunjang pelaksanaan kerja. Outcome adalah semua nilai yang diperoleh dan dirasakan pegawai. Comparison person adalah seseorang pegawai dalam organisasi yang sama, seseorang pegawai dalam organisasi yang berbeda atau dirinya sendiri dalam pekerjaan sebelumnya.

\section{Teori perbedaan (Discrepancy theory)}

Teori ini pertama kali dipelopori oleh Proter. Ia berpendapat bahwa mengukur kepuasan dapat dilakukan dengan cara menghitung selisih antara apa yang seharusnya dengan kenyataan yang dirasakan 
pegawai.

Teori pemenuhan kebutuhan (Need fulfillment theory)

Kepuasan kerja pegawai bergantung pada terpenuhi atau tidaknya kebutuhan pegawai. Pegawai akan merasa puas apabila ia mendapatkan apa yang dibutuhkannya.

\section{Teori pandangan politik (Social reference group theory)}

Kepuasan kerja pegawai bukanlah bergantung pada pemenuhan kebutuhan saja, tetapi sangat bergantung pada pandangan dan pendapat kelompok yang oleh para pegawai dianggap sebagai kelompok acuan.

\section{Faktor-faktor Kepuasan Kerja}

Blum dalam Edy (2009:77) "Mengemukakan faktor-faktor yang memberikan kepuasan" sebagai berikut:

\section{Faktor individual}

Meliputi umur, kesehatan, watak, dan harapan.

\section{Faktor sosial}

Meliputi hubungan kekeluargaan, pandangan pekerja, kebebasan berpolitik, dan hubungan kemasyarakatan.

\section{Faktor utama dalam pekerjaan}

Meliputi upah, pengawasan, ketentraman kerja, kondisi kerja, dan kesempatan untuk maju. Selain itu, juga penghargaan terhadap kecakapan, hubungan sosial dalam pekerjaan, ketepatan dalam menyelesaikan konflik antar manusia, perasaan diperlakukan adil baik yang menyangkut pribadi maupun tugas.

Menurut Gilmer dalam Edy (2009:77) faktor-faktor kepuasan kerja adalah :

\section{Kesempatan untuk maju}

Dalam hal ini ada tidaknya kesempatan untuk memperoleh pengalaman dan peningkatan kemampuan selama kerja.

\section{Keamanan kerja}

Faktor ini disebut sebagai penunjang kepuasan kerja, baik bagi karyawan. Keadaan yang aman sangat mempengaruhi perasaan karyawan selama kerja.

\section{Gaji}

Gaji lebih banyak menyebabkan ketidakpuasan, dan jarang orang mengespresikan kepuasan kerjanya dengan sejumlah uang yang diperolehnya.

\section{Perusahaan dan manajemen}

Perusahaan dan manajemen yang baik adalah yang mampu memberikan situasi dan kondisi kerja yang stabil. Faktor ini yang menentukan kepuasan kerja karyawan.

\section{Pengawasan}

Sekaligus atasannya. Supervise yang buruk dapat berakibat.

\section{Faktor intrinsik dari pekerjaan}

Atribut yang ada dalam pekerjaan mensyaratkan keterampilan tertentu sukar dan mudahnya serta kebanggaan akan tugas dapat meningkatkan atau mengurangi kepuasan.

\section{Kondisi kerja}


Termasuk disini kondisi tempat, ventilasi, penyiaran.

\section{Aspek sosial dalam pekerjaan}

Merupakan salah satu sikap yang sulit digambarkan tetapi dipandang sebagai faktor menunjang puas atau tidak puas dalam kerja.

\section{Komunikasi}

Komunikasi yang lancar antar karyawan dengan pihak manajemen banyak dipakai alasan untuk menyukai jabatannya dalam hal ini adanya kesediaan pihak atasan untuk mau mendengar, memahami, dan mengakui pendapat ataupun prestasi karyawannya sangat berperan dalam menimbulkan rasa puas terhadap kerja.

\section{Fasilitas}

Fasilitas rumah sakit, cuti, dana pensiun, atau perumahan merupakan standar suatu jabatan dan apabila dapat dipenuhi akan menimbulkan rasa puas.

\section{METODELOGI PENELITIAN}

Obyek atau sasaran untuk melakukan penelitian pada PDAM Tirta Jeneberang Kab Gowa, yang beralamat di jalan Alternatif Swadaya No 17. Penelitian ini dilaksanakan selama 1 bulan yakni 1 Februari sampai 29 Maret 2018.
Adapun yang menjadi populasi dalam penelitian ini adalah delapan puluh lima (85) orang seluruh karyawan dengan jumlah karyawan tetap empat puluh dua (42) orang, dan karyawan kontrak empat puluh tiga (43) orang pada PDAM Tirta Jeneberang Kab.Gowa

Untuk mendapatkan sampel maka digunakan sampel non probability sampling, menurut Sugiyono (2013;98) teknik non probability yakni teknik pengambilan sampel yang tidak memberi peluang atau kesempatan sama bagi setiap unsur atau anggota populasi untuk dipilih menjadi sampel. Teknik non probability sampling yakni teknik penentuan sampel dengan pertimbangan tertentu.

Berdasarkan penjelasan tersebut, maka jumlah populasi yang dijadikan sampel dalam penelitian ini, yakni sebanyak empat puluh dua (42) orang karyawan, tidak termasuk karyawan kontrak pada PDAM Tirta Jeneberang Kabupaten Gowa.

\section{HASIL PENELITIAN DAN PEMBAHASAN}

\section{Karakteristik Responden}

Karakteristik menurut jenis kelamin karyawan pada PDAM Tirta Jeneberang Kabupaten Gowa.

\section{Populasi dan sampel}

Tabel 4: Persentase responden berdasarkan jenis kelamin

\begin{tabular}{|c|c|c|c|}
\hline No & Jenis kelamin & Jumlah Responden (orang) & Persentase \% \\
\hline 1 & Laki-Laki & 22 & 52,38 \\
\hline 2 & Perempuan & 20 & 47,62 \\
\hline \multicolumn{2}{|c|}{ Total Responden } & 42 & 100 \\
\hline
\end{tabular}

Sumber : Data diolah, 2018 
Tabel 4 diatas menjelaskan bahwa partisipasi responden berjenis kelamin perempuan yaitu 20 orang atau sebesar $47,62 \%$, sedangkan partisipasi berjenis kelamin laki-laki yaitu 22 orang atau sebesar $52,38 \%$.

\section{Analisis Kepuasan Kerja Karyawan}

Tabel 10 : Hasil pengolahan kuesioner

\begin{tabular}{|c|c|c|c|c|c|}
\hline \multirow[t]{2}{*}{ Responden } & \multicolumn{2}{|c|}{ Kepuasan Kerja } & \multicolumn{2}{|c|}{ Kinerja Karyawan } & \multirow[b]{2}{*}{$X Y$} \\
\hline & $\mathrm{X}$ & $X^{2}$ & $\mathrm{Y}$ & $\mathrm{Y}^{2}$ & \\
\hline 1 & 35 & 1225 & 42 & 1764 & 1470 \\
\hline 2 & 35 & 1225 & 39 & 1521 & 1365 \\
\hline 3 & 32 & 1024 & 30 & 900 & 960 \\
\hline 4 & 35 & 1225 & 47 & 2209 & 1645 \\
\hline 5 & 32 & 1024 & 38 & 1444 & 1216 \\
\hline 6 & 37 & 1369 & 37 & 1369 & 1369 \\
\hline 7 & 35 & 1225 & 35 & 1225 & 1225 \\
\hline 8 & 35 & 1225 & 38 & 1444 & 1330 \\
\hline 9 & 37 & 1369 & 38 & 1444 & 1406 \\
\hline 10 & 35 & 1225 & 32 & 1024 & 1120 \\
\hline 11 & 35 & 1225 & 36 & 1296 & 1260 \\
\hline 12 & 32 & 1024 & 33 & 1089 & 1056 \\
\hline 13 & 34 & 1156 & 32 & 1024 & 1088 \\
\hline 14 & 31 & 961 & 31 & 961 & 961 \\
\hline 15 & 34 & 1156 & 41 & 1681 & 1394 \\
\hline 16 & 34 & 1156 & 41 & 1681 & 1394 \\
\hline 17 & 37 & 1369 & 35 & 1225 & 1295 \\
\hline 18 & 37 & 1369 & 43 & 1849 & 1591 \\
\hline 19 & 38 & 1444 & 41 & 1681 & 1558 \\
\hline 20 & 39 & 1521 & 40 & 1600 & 1560 \\
\hline 21 & 36 & 1296 & 42 & 1764 & 1512 \\
\hline 22 & 37 & 1369 & 42 & 1764 & 1554 \\
\hline 23 & 40 & 1600 & 41 & 1681 & 1640 \\
\hline 24 & 40 & 1600 & 39 & 1521 & 1560 \\
\hline 25 & 42 & 1764 & 41 & 1681 & 1722 \\
\hline 26 & 42 & 1764 & 42 & 1764 & 1764 \\
\hline 27 & 35 & 1225 & 39 & 1521 & 1365 \\
\hline 28 & 34 & 1156 & 40 & 1600 & 1360 \\
\hline 29 & 37 & 1369 & 39 & 1521 & 1443 \\
\hline 30 & 32 & 1024 & 39 & 1521 & 1248 \\
\hline 31 & 34 & 1156 & 39 & 1521 & 1326 \\
\hline 32 & 36 & 1296 & 36 & 1296 & 1296 \\
\hline 33 & 34 & 1156 & 31 & 961 & 1054 \\
\hline 34 & 35 & 1225 & 32 & 1024 & 1120 \\
\hline 35 & 38 & 1444 & 39 & 1521 & 1482 \\
\hline 36 & 36 & 1296 & 47 & 2209 & 1692 \\
\hline 37 & 37 & 1369 & 43 & 1849 & 1591 \\
\hline 38 & 42 & 1764 & 47 & 2209 & 1974 \\
\hline 39 & 36 & 1296 & 35 & 1225 & 1260 \\
\hline
\end{tabular}

(C) 2019 STIE TDN. All rights reserved
Bentuk persamaan yang dipakai untuk menentukan sifat antara kepuasan kerja dan kinerja karyawan adalah regeresi sederhana. Tujuannya untuk mengetahui pengaruh antara variabel yang ada, dimana regresi pada dasarnya adalah mencari suatu persamaan pengetahuan tentang suatu variabel dapat digunakan untuk memperkirakan variabel lainnya. 


\begin{tabular}{|c|c|c|c|c|c|}
\hline 40 & 35 & 1225 & 39 & 1521 & 1365 \\
\hline 41 & 36 & 1296 & 35 & 1225 & 1260 \\
\hline 42 & 32 & 1024 & 37 & 1369 & 1184 \\
\hline$\sum$ & $\mathrm{X}=1505$ & $\mathrm{X}^{2}=54231$ & $\mathrm{Y}=1613$ & $\mathrm{Y}^{2}=62699$ & $\mathrm{XY}=58035$ \\
\hline
\end{tabular}

Sumber : Data diolah, 2018

Nilai a dan b dapat dihitung sebagai berikut :

$\mathrm{b}=\frac{n\left(\sum x y\right)-\left(\sum x\right)\left(\sum y\right)}{n\left(\sum x^{2}\right)-\left(\sum x\right)^{2}}$

$\mathrm{b}=\frac{42(58035)-(1505)(1613)}{42(54231)-(1505)^{2}}$

$\mathrm{b}=\frac{2437470-2427565}{2277702-2265025}$

$\mathrm{b}=\frac{9905}{12677}$

$\mathrm{b}=0,78$

Sedangkan nilai a dapat dihitung sebagai berikut :

$\mathrm{a}=\frac{\sum y}{n}-b \frac{\sum x}{n}$

$a=\frac{1613}{42}-(0,78) \frac{1505}{42}$

$\mathrm{a}=38,40-27,95$

$\mathrm{a}=10,4$

Dari perhitungan diatas, maka persamaan regresi linear sederhana antara variabel $\mathrm{x}$ dan y adalah :

$$
Y=10,4+0,78 x
$$

Persamaan linear sederhana menjelaskan bahwa adanya pengaruh antara kepuasan kerja terhadap kinerja karyawan pada PDAM Tirta Jeneberang Kabupaten Gowa yaitu 0,78 berarti setiap penambahan kepuasan kerja sebesar 1 satuan maka diharapkan kinerja karyawan meningkat sebesar 0,78 . Nilai intersap atau konstanta sebesar 10,4 yang artinya tanpa adanya variabel kepuasan kerja $(\mathrm{X}=0)$, maka kinerja karyawan pada PDAM Tirta Jeneberang Kab.Gowa tetap sebesar 10,4.

\section{Korelasi Sederhana}

Dari hasil tabulasi sebelumnya, perhitungan kuesioner untuk mencari keterkaitan antara variabel kepuasan kerja dan variabel kinerja karyawan dapat dilihat pada rumus dibawah ini :

$\mathrm{r}=$ Nilai Koefisien Korelasi $\mathrm{n}=$ Sampel

$\mathrm{Y}=$ Kinerja Karyawan

$\mathrm{X}=$ Kepuasan Kerja

$r$

$$
\begin{aligned}
& =\frac{n \sum x y-\left(\sum x\right)\left(\sum y\right)}{\sqrt{\left\{n \sum x^{2}-\left(\sum x\right)^{2}\right\}\left\{n \sum y^{2}-\left(\sum y\right)^{2}\right\}}} \\
& =\frac{42(58035)-(1505)(1613)}{\sqrt{\left\{42(54231)-(1505)^{2}\right\}\left\{42(62699)-(1613)^{2}\right\}}} \\
& \text { r } \\
& =\frac{2437470-2427565}{\sqrt{\{2277702-2265025\}\{2633358-2601769\}}} \\
& =\frac{9905}{\sqrt{(12677)(31589)}} \\
& r \\
& =\frac{9905}{\sqrt{400453753}} \\
& r \\
& =\frac{9905}{20011,34} \\
& r=0,49
\end{aligned}
$$

Koefisien korelasi dinyatakan dalam persentase (\%) sesuai dengan yang telah dikemukakan (C) 2019 STIE TDN. All rights reserved 
sebelumnya pada tabel 3 mengenai interprestasi nilai $r$, sehingga keeratan kedua variabel berada dalam kategori cukup kuat.

Berdasarkan perhitungan tersebut di atas, maka pengaruh antara kepuasan kerja dengan kinerja karyawan adalah positif, yaitu 0,49 yang berada dalam kategori cukup kuat. Hal ini sesuai dengan pendapat Sugiyono (2013:214), yang dimana telah dijelaskan pada tabel 3 tentang persentase keeratan berada pada nilai antara 0,40-0,599 yang berada dalam kategori cukup kuat.

\section{Koefisien Determinisasi (r2)}

Adapun untuk mengetahui besarnya (\%) pengaruh variabel $\mathrm{X}$ terhadap $\mathrm{Y}$ dengan nilai sebagai berikut :

$\mathrm{r} 2=(0,49 \times 0,49)$

r2 $=0,2401$ atau $24,01 \%$

ini berarti bahwa hubungan antara kepuasan kerja dengan kinerja karyawan sebesar 0,2401 atau $24,01 \%$ sedangkan $75,99 \%$ lainnya adalah faktor-faktor variabel yang tidak diteliti seperti kepemimpinan, motivasi.

\section{Uji t hitung}

Untuk membuktikan signifikan atau tidak signifikannya pengaruh kepuasan kerja terhadap kinerja karyawan, maka perlu dilakukan pengujian terhadap koefisien tersebut apakah dapat diterima atau tidak dengan menggunakan uji $\mathrm{t}$ hitung, dengan menggunakan rumus persamaan sebagai berikut :

Menetukan nilai ttabel dengan uji taraf nyata $(\alpha)=0,05(5 \%)$ :

$\mathrm{db} \quad=(\mathrm{n}-2)$

$\mathrm{db} \quad=42-2$

$\mathrm{db}=40$

Maka, nilai ttabel $(0,05 ; 40)=1,684$ (lihat lampiran tabel nilai t)

Perhitungan Uji t hitung :
Dari hasil pengujian tersebut diperoleh nilai t-hitung sebesar 3,55 sedangkan nilai t-tabel sebesar 1,684 dengan demikian dapat disimpulkan bahwa nilai t-hitung > t-tabel $(3,55>$ 1,684) sehingga hipotesis yang dikemukakan yakni diduga bahwa kepuasan kerja berpengaruh terhadap kinerja karyawan pada PDAM Tirta Jeneberang Kabupaten Gowa, selanjutnya dapat digambarkan melalui kurva t-tabel mengenai pengaruh kepuasan kerja terhadap kinerja karyawan pada PDAM Tirta Jeneberang Kabupaten Gowa, sebagai berikut :

$$
\begin{gathered}
t_{\text {hitung }}=\frac{r \sqrt{n-2}}{\sqrt{1-r^{2}}} \\
t_{\text {hitung }}=\frac{0,49 \sqrt{42-2}}{\sqrt{1-0,2401}} \\
t_{\text {hitung }}=\frac{0,49 \sqrt{40}}{\sqrt{0,7599}} \\
t_{\text {hitung }}=\frac{0,49 \times 6,324}{0,871} \\
t_{\text {hitung }}=\frac{3,0987}{0,871} \\
t_{\text {hitung }}=3,55
\end{gathered}
$$

Dari hasil pengujian tersebut diperoleh nilai t-hitung sebesar 3,55 sedangkan nilai t-tabel sebesar 1,684 dengan demikian dapat disimpulkan bahwa nilai t-hitung > t-tabel $(3,55>1,684)$ sehingga hipotesis yang dikemukakan yakni diduga bahwa kepuasan kerja berpengaruh terhadap kinerja karyawan pada PDAM Tirta Jeneberang Kabupaten Gowa, selanjutnya dapat digambarkan melalui kurva t-tabel mengenai pengaruh kepuasan kerja terhadap kinerja karyawan pada PDAM Tirta Jeneberang Kabupaten Gowa, sebagai berikut : 
Gambar 3: Kurva hasil uji-t

Daerah penolakan $\mathrm{H}_{\mathrm{o}}$ / terima $\mathrm{H}_{\mathrm{a}}$

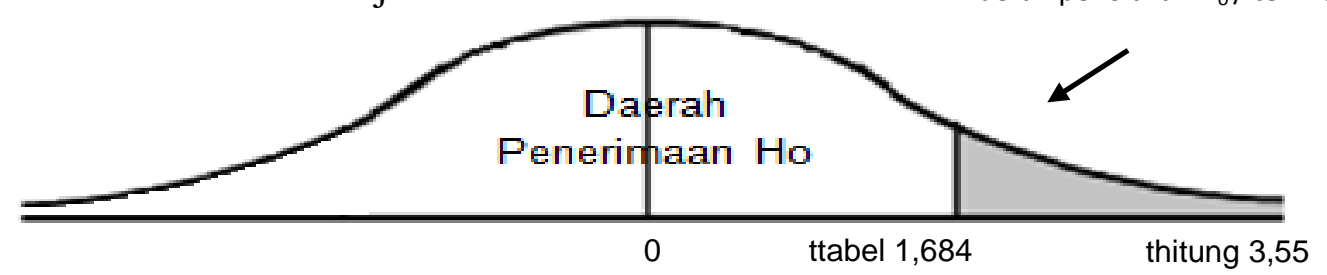

Sumber : Data diolah, 2018

Hasil perhitungan t-hitung dan gambar kurva hipotesis diketahui bahwa variabel bebas (kepuasan kerja) tersebut memiliki hubungan yang positif dan signifikan terhadap peningkatan variabel kinerja karyawan. Hal ini ditunjukkan oleh keberadaan variabel bebas tersebut dengan t-hitung pada sebelah kanan kurva pengujian hipotesis dan memiliki nilai yang lebih besar dari nilai kritis $(1,684: \alpha=0,05)$. Hal ini juga memberikan petunjuk bahwa kedua variabel yaitu kepuasan kerja dan kinerja karyawan memililki hubungan yang positif dan signifikan, artinya setiap perubahan yang terjadi karena perlakuan peningkatan variabel kepuasan kerja maka variabel lainnya yaitu variabel kinerja juga dapat meningkat.

Hasil penelitian yang telah dilakukan sesuai dengan teori yang dikemukakan oleh Edy (2009:83) "Kepuasan kerja karyawan adalah merupakan masalah penting yang diperhatikan dalam hubungannya dengan produktivitas kerja karyawan dan ketidakpuasan sering dikaitkan dengan tingkat tuntutan dan keluhan pekerjaan yang tinggi. Hasil penelitian ini diperkuat peneliti terdahulu yang dilakukan oleh Novita (2010), Kartika (2012), Roisul (2012), Furi (2015) dan Irhamatul (2016) yang kesimpulannya menyatakan bahwa kepuasan kerja berpengaruh positif dan signifikan terhadap kinerja karyawan.

\section{KESIMPULAN}

Dari hasil penelitian mengenai pengaruh kepuasan kerja terhadap kinerja karyawan pada PDAM Tirta Jeneberang Kabupaten Gowa pernyataan mengenai kepuasan kerja dapat dilihat pada analisis deskriptif variabel kepuasan kerja didapatkan hasil sebesar 71,67\% apabila dikaitkan dengan kriteria yang telah ditentukan termasuk dalam kriteria baik, sedangkan pada analisis deskriptif kinerja didapatkan hasil sebesar $76,80 \%$ apabila dikaitkan dengan kriteria yang telah ditentukan termasuk dalam kriteria baik.

Selanjutnya hasil pembahasan dengan menggunakan analisis statistik yakni mencari pengaruh kepuasan kerja terhadap kinerja karyawan pada PDAM Tirta Jeneberang Kabupaten Gowa, maka didapatkan hasil dari persamaan regresi linear sederhana yakni : $\mathrm{Y}=10,4+0,78 \mathrm{X}$, hasil dari persamaan korelasi yakni $=0,49$ hasil dari koefisien determinasinya adalah sebesar 0,2401 atau $24,01 \%$. Dan setelah melakukan perhitungan uji $\mathrm{t}$ didapatkan hasil 3,55 > 1,684 maka Ha diterima dan menolak Ho. jadi, kesimpulan pada penelitian ini adalah bahwa pada tingkat kepuasan kerja 95\%, maka benar ada pengaruh positif dan signifikan antara kepuasan kerja terhadap kinerja karyawan pada PDAM Tirta Jeneberang kab. Gowa. 


\section{Saran}

Berdasarkan kesimpulan dari penelitian ini, maka dapat diketahui bahwa kepuasan kerja berpengaruh positif dan signifikan terhadap kinerja karyawan. Oleh karena itu saran yang dapat diberikan kepada pihak PDAM Tirta Jeneberang Kabupaten Gowa adalah :

1. Bedasarkan hasil analis tanggapan responden pada tabel 8 tentang kepuasan kerja. Maka PDAM Tirta Jeneberang Kabupaten Gowa diharapkan mampu meningkatkan dan mempertahankan kepuasan kerja yang ada, meningkatkan kompetensi karyawan, dan meningkatkan kebijakan yang ada dalam perusahaan.

2. Berdasarkan hasil analisis tanggapan responden pada tabel 9 tentang kinerja, bahwa kinerja karyawan sudah cukup baik dalam melaksanakan pekerjaannya. Oleh karena itu kinerja dalam perusahaan ini sudah cukup baik dan harus dipertahankan.

\section{DAFTAR PUSTAKA}

A.A Anwar. Prabu. Mangkunegara. 2016. Manajemen Sumber Daya Manusia Perusahaan. Bandung, PT. Remaja Rosdakarya.

Edy. Sutrisno. 2009. Menajemen Sumber Daya Manusia. Jakarta, Kencana.

Eko. Widodo. Suparno. 2015. Manajemen Pengenbangan Sumber Daya Manusia. Yogyakarta. Pustaka Pelajar.

Emron Edison, Dkk. 2016. Manajemen Sumber Daya Manusia. Bandung, Alfabeta.

Furi. Amelia. 2015. Pengaruh Kepuasan Kerja Terhadap Kinerja Karyawan Pada PT. SMART TBK di Surabaya.
Harmono. 2011. Manajemen Sumber Daya Manusia. Edisi Kesatu. Cetakan Kedua. Jakarta, Erlangga.

Irhamatul. Jariyanti. 2016. Pengaruh Kepuasan Kerja Terhadap Kinerja karyawan Pada PT. Bank Pembiayaan Rakyat Syariah Bhakti Sumekar Kabupaten Sumenep.

Kartika. Amelia. 2012. Pengaruh Kepuasaan Kerja Terhadap Kinerja Karyawan Pada Agen PT. Jasa Raharja Putera Cabang Jakarta.

Malayu. Hasibuan. 2016. Manajemen Sumber Daya manusia. Edisi Revisi. Jakarta. PT. Bumi Aksara.

Novita. Marlia. 2010. Pengaruh Kepuasan Kerja Terhadap Kinerja Karyawan CV Alam Prima computer Bandar Lampung.

Rahmat. 2016. Pemberdayaan Sumber Daya Manusia. Makassar. Umitoha Ukhuwah Grafika.

Roisul. Huda. 2012. Pengaruh Kepuasan Kerja terhadap Kinerja Karyawan PT. Joyo Bekti Indah Surabaya.

Sedarmayanti. 2017. Perencanaan dan Pengembangan Sumber Daya Manusia. Bandung. RefikaAditama.

Sugiyono. 2013. Metode penelitian Administrasi.Edisi ke-14. Bandung, Alfabeta.

Sugiyono. 2017. Metode penelitian Kuantitatif Kualitatif dan $R \& D$. Bandung, Alfabeta.

Syamsi. I. 2010. Perilaku Keorganisasian. Edisi Pertama. Jakarta, Erlangga

Wilson. Bangun. 2012. Manajemen Pengembangan Sumber Daya. Jakarta, Erlangga. 